\title{
A ROADMAP TO THE PROFESSIONALIZATION OF GUIDANCE AND COUNSELLING IN NIGERIA
}

\author{
Aluede, Oyaziwo \\ Department of Educational Foundations \& Management \\ Ambrose Alli University \\ P.M.B. 14, Ekpoma 310001 \\ Nigeria \\ email: oyaziwoaluede@yahoo.com
}




\section{Abstract}

The paper examined guidance and counselling profession in Nigeria, which is recognized to have existed in Nigeria since 1959. Against the backdrop of poor recognition of the profession in Nigeria, this paper examined the status of the profession and provided ways of making the field a recognizable height in Nigeria. Suggestions on how to address issues of certification, licensure, and continuing education among others, were provided

Key Words: Professional Counselling, Counsellor preparation, Professionalism, Nigeria

\section{Introduction}

Contrary to the belief that counselling as a process began in the USA in the early 1900s when Clifford Beers raised the awareness of Americans to the treatment of mental illness, it could be argued that counselling began in Africa and dates back to the origin of human (Aluede, McEachern \& Kenny, 2005). Then counselling was informal because no special skills were required to discharge associated responsibilities. Rather, experience in the art, which often came with age was all that was required to counsel. This assertion is further strengthened by the position of Schmidt (1993) that historical accounts and guidance literature are filled with reference to philosophers, wizards, fortune tellers, medicine men and others who in their unique and sometimes mythic ways created the advent of the helping profession. Hence guidance in the past was seen as a process of directing, piloting, assisting, guiding, which was rendered by parents/guardians, priests, imams, older siblings and so on ( Odebunmi, 1985). This is further confirmed by Gibson and Mitchell (2003) that the first counterparts of professional counsellors were perhaps the elder of ancient tribes who advised the youths and guided them towards responsible decision and behaviour.

Counselling as practiced today, is largely an American phenomenon (Bojuwoye, 1992), and has been defined by Hui (1994, 
as cited on Hui, 2000) as one of the activities offered to help individuals face difficulties and cope effectively. It is the process of establishing a relationship to identify people's needs, design strategies and services to satisfy needs and actively assist in carrying out plans of actions to help people make informed decisions, solve problems, develop awareness, and lead healthier lives ( Schmidt, 1993).

Parrot (1997, as cited in Aluede et al, 2005) asserts that the most accurate definition of counselling could be what counsellors actually do, which involves the following:

1. having a personal commitment to help clients;

2. being given a certain degree of authority and thus inspiring faith and hope in clients;

3. acting as a mediator between suffering clients and the larger society;

4. helping clients release emotions, rethink problems and restore morale simply by listening in an empathic manner;

5. creating a framework for change by providing exploratory schemes that help clients understand their conflicts and pains; and

6. being actively involved in the process of change, usually over a number of session.

\section{The Emergence of Professional Counselling in Nigeria}

It is common knowledge in our counselling practice in Nigeria, that professional counselling has existed as career counselling in Nigeria since 1959 (cf. Aluede, 2000). The process of having counselling institutionalised in Nigerian school system began with the efforts of a group of catholic nuns that organized a career workshop at St Theresa's College Oke-Ado, Ibadan. It is reported in the guidance literature in Nigeria that this effort and several others thereafter culminated in the establishment of the Nigerian Career Council that has now metamorphosed into the Counselling Association of Nigeria (Aluede \& Imonikhe, 2006; Aluede, 2006). 
Following of the civil war in Nigeria between July 29, 1967and January 15, 1970, there was the dire need to rehabilitate the war victims especially the displaced school children (Egbule, 1997, as cited in Iwuama, 1998). This was also instrumental to the institutionalisation of counselling programmes in schools. In addition, is the enormous difficulties that secondary school students whom were being exposed to a new form of educational policy (6-3-3-4) would face, particularly at the period of transition from junior secondary school level; and the transition between secondary schools and the labour markets was also another force that led to the emergence of guidance and counselling as an educational service in the national policy on education.

\section{The Status of Professional Counselling in Nigeria}

Guidance literature (i.e. Aluede, Afen- Akpaida \& Adomeh, 2004; Iwuama, 1998) has provided a very important perspective about the status of professional counselling in Nigeria, to include the following:

i. school counselling programmes exist in some secondary schools;

ii. all the federal government owned secondary schools have functional school counselling centres with professional counsellors in charge;

iii. in most state - owned secondary schools some form of career counselling programmes exist and usually provided by career masters/mistresses;

iv. in most secondary schools, counsellors are saddled with teaching and other ancillary responsibilities to the detriment of their counselling practice;

v. many Nigerian counsellor education departments are making remarkable contributions to the development of counselling practice in Nigeria through the training of potential counsellors even at the undergraduate levels so as to meet with the high demand in the society; 
vi. many universities have/are establishing counselling and guidance departments and recruiting specialists for teaching appointments. Many of these counsellor educators are now in the ranks of professors.

vii. The Counselling Association of Nigeria (CASSON) is yet to assume a legal status in spite of the fact that the body has existed since the 1960s as Ibadan Career Council and later Nigerian Career Council, because of the absence of legislation that clearly defines the functions, academic and professional qualifications and ethical responsibilities of counsellors. It has allowed anybody to ascribe to himself/herself the name "counsellor"

viii. the Counselling Association of Nigeria is yet to advance standards for professionalism by way of promoting professional conducts among members.

ix. though the Counselling Association of Nigeria (CASSON) organizes her annual conferences every August and publishes some of the empirical works in her journal called the COUNSELLOR, and other nonempirical works in the Association's conference proceedings as a way of advancing capacity building in the counselling field, it is common knowledge that activities during such conferences are gradually losing the academic flavour that may have been desired

$x$. many of the fore-runners in counselling in Nigeria, especially in Nigeria universities who certify potential counsellor educators, do not have a single training in guidance and counselling. That is to say, many of the lecturers in this category have higher degrees in fields other than counselling, yet train students in counselling

xi. presently, there is no law guiding the practice of counselling. Hence anybody can assume the role of counsellor 


\section{Roadmap for the Professionalization of Counselling in Nigeria}

The Counselling Association of Nigeria (CASSON) has a lot to do if counselling and guidance must assume an enviable height in Nigeria. At the moment, the Counselling Association of Nigeria has not specified standards of professionalism by way of professional conduct, including malpractice, insurance for members, or by way of stimulating, promoting and conducting programmes of scientific benefits to the emerging counselling profession in Nigeria. Perhaps, as a means of achieving professionalism, CASSON has set up the Certification and Licensure Board (CALB), which has also prepared and distributed a document to members of CASSON proposing the process for professionalization of the counselling and guidance profession, which members are enjoined to meet. Adherence to the provisions/requirements is one issue CASSON may not be able to guarantee, largely because CALB would be able to achieve its set goals only if counselling is recognized as a profession by relevant authorities. At the moment, there is no legislation recognizing CASSON as a professional body in Nigeria. It is only a non-profit organization registered before the Corporate Affairs Commission (CAC) for the purpose of providing an umbrella for her members to fellowship. It is not recognized to provide further education or continuing education for her members. It is not vested with authorities to certify its membership; it cannot discipline any of its members for professional misconduct. If we have to talk of professionalization the first thing we must bear in mind is professional identity. Hence I suggest that an act be proposed before the National Assembly for a legislation recognizing counselling as a profession and also spelling out the requirements and our professional responsibilities that members or potential members must strive to meet

CASSON has a journal called the "COUNSELLOR" that is released once annually, which publishes most of the empirical papers presented at the CASSON annual conference. I make bold to say that presently, the review process of the journal is far from being rigorous. A case is therefore being made that the Editorial 
Board of the journal be strengthened and made independent (that will also draw competent scholars as members) of the CASSON executives and its frequency in terms of publication can be extended to twice or thrice in a year. Rather than rely on conference papers, it should seek manuscripts of diverse interests that are geared towards advancing counselling practice, rather than those that merely satisfy "the publish or perish" palaver that has now made our colleagues in most tertiary institutions in Nigeria to now publish anything all in the name of publications just to satisfy the requirements of attaining higher position in the academia.

The counselling profession is becoming highly diverse. Many national associations across the globe are responding in that regard. Specialized sub-divisions within the general counselling field are exemplified in the affiliates that are beginning to emerge. In the US, for example, there are about 17 sub-divisions in the counselling profession, as exemplified in the affiliates of American Counselling Association (ACA). With most of these sub-divisions having there own guidelines for practice, and also floating highly specialized journals with very competent members serving in the respective Editorial Boards. Thus, in the US we can speak of Career Development Quarterly, Counsellor Education and Supervision, Journal of Humanistic Counselling, Education and Development, etc, outside the parent journal - Journal of Counselling and Development. The counselling profession in Nigeria must think along this line for maximum benefit of her members.

In Nigeria there is a great disparity in both courses and contents of courses in counsellor preparation from one university to another. This is largely due to absence of an accrediting body that would have set Minimum Accreditation Standards (MAS). Even though the National Universities Commission (NUC) exists, CASSON's accrediting unit ought to compliment the NUC. Other professions like Law, Medicine, and even Medical Laboratory Sciences have been able to forge such alliance. Therefore, I recommend that CASSON must forge on to have an organ that will be vested with the responsibilities of accrediting counsellor 
education programmes in Nigeria universities. CASSON can learn from the United States of America (USA) experience. In the US, the Council for the Accreditation of Counselling and Related Educational Programs (CACREP) is the body that is vested with the responsibility of accrediting various counselling programmes in most US universities (and now being extended to Canadian universities) despite the presence of other accrediting body for most educational programmes.

Counsellor education programmes in Nigeria universities are becoming too generalized and lacking in focus in terms of specialization; it is a known fact that counselling is a very wide field (Aluede et al, 2005). In spite of the diverse field of counselling, all aspects are lumped together in the process of training counsellors. Today, in the US, one can earn specialized degrees like Masters in School Counselling, Masters in Mental Health Counselling, and Masters in Rehabilitation Counselling and so on. Even though university of Ibadan has over the years attempted to provide areas of specialization in counselling and guidance, the Masters in Personnel Psychology (MPP) currently run by the Department of Guidance and Counselling of the University bear no direct relevance to counselling and her sub-divisions.

Nigeria, with a population of about 140 million people and over 350 spoken languages is obviously a multi- cultural nation with very district ethnic nationalities. Unfortunately, no emphasis is placed on appreciating the diverse nature of our country in our guidance and counselling programmes in Nigerian universities. Hence majority of universities offering degree in guidance and counselling have not appreciated the need to infuse multi-cultural counselling into their programmes (Aluede \& Maliki, 2000). In the US, which is also a multi-cultural nation, the inclusion of multiculturalization has been made mandatory for all CACREP accredited counsellor education programmes, as it is included in one of the core curriculum content areas. It is our hope that CASSON can learn from this experience by also including multiculturalism in guidance and counselling training in Nigerian universities. 
Other issues connected with guidance and counselling programmes in Nigeria are those of Licensure and Certification. Till date, there are no formally recognized and mandatory educational requirements for certification as a professional counsellor beyond having obtained a university degree in guidance and counselling (Aluede et al, 2005) or educational psychology with specialization in school counselling. Even though CASSON over the years has attempted to raise the minimum educational requirements for certification to a Master's degree in guidance and counselling or a Bachelor's degree in guidance and counselling with five years of work experience, it is not unusual for graduates with bachelor's degree in guidance and counselling without any work experience to be offered employment as guidance counsellors in secondary schools in Nigeria and even progressing in the career to become Director of Counselling services in the ministry of education. In the US for instance, the National Board for Certified Counsellors (NBCC) provides national certification for individual counsellors. This certification programme recognized counsellors who have met standards in training and experience and passed the National Counsellor Examination (NCE). At the moment, NBCC is beginning to offer presentations on standards and certifications internationally in collaboration with the International Association for Counselling (IAC). NBCC is already partnering with other countries such as Britain, Australia, Canada and New Zealand and studying how credentialing of counsellors is carried out in these countries. The President of African Association for Guidance and Counselling (AAG \& C), Dan Bushamane has approached NBCC for assistance in creating certification standards for African counsellors. How far this collaboration between NBCC and AA G\&C has gone we do not know. CASSON is hereby urged to partner with other national counselling associations with a view to creating certification standards for both practicing and potential counsellors in Nigeria. By so doing, the counselling profession may begin to assume a place of pride in the Nigerian educational system 
At the moment, the practice of guidance and counselling in Nigeria is directed largely towards helping the post-primary school child meet with his/her needs and make necessary adjustments to life. Even in our training, all efforts are geared towards meeting this goal of the national policy on Education, which states "in view of the apparent ignorance of many young people about career prospects, and in view of personality maladjustment among school children, career officers and counsellors will be appointed for the post primary schools in Nigeria" (Federal Government of Nigeria, 2004). This provision has largely accounted for the support of counselling services in our secondary schools with little or no emphasis on counselling services at both the primary and tertiary levels of education in Nigeria. Even though, few universities like University of Benin, University of Ibadan, and some others, attempt to establish counselling centres, records abound that these centres are not headed by full-time counsellors. Rather, the centres are controlled by the academic departments offering guidance and counselling programmes, which in turn use them essentially as teaching/demonstration centres for counsellors in training. We hereby advocate that counselling centres in our universities must consider employing fulltime counsellors to deal with the numerous pressures from our universities students.

It is a known fact that students of institutions of higher education need more help in building their life long career than they did during the era of static career planning (Ritook, 1998). A new tendency in Nigerian universities is that few students are getting admitted because of the newly introduced NUC's "carrying capacity". This implies that the requirements for admission has been strengthened, if not raised, by the introduction of Post Universities Matriculation Examination (PUME) leading to more and more prospective students not getting a place in our colleges. In other situations, many now get enrolled in programmes especially the part time or sandwich programmes, or in courses that they have least interests for. Many of these students desire to transfer to programmes at the end of the first or second academic session(s) to 
programmes of interest or switch from the sandwich or part time programmes to the full time programmes, which have now become nightmarish. This is leading more students quitting or receiving no degree in the end. These challenge counsellors with the task of: Preventing the unjustified quitting of college by students and need to counsel them and offer career counselling services to those who inevitably leave an institution. No doubt, information about job opportunities, possibilities about further education; jobs abroad, and how to get funding for studies (Ritook, 1998) will be of great assistance. All these can be addressed if counselling centres in our universities are made to address students' concerns rather than serve as mere demonstration/teaching centres

Counselling, the world over, is one of the most dynamically developing professions. Hence, new forms of activities and professional trainings are emerging. In the US, we speak of mental health counselling, employment counselling, family counselling, rehabilitation counselling, school counselling, college counselling, and spiritual counselling and so on. In short American Counselling Association (ACA) has over 17 specialty divisions. With regards to each specialty, there often exist professional associations, which establish training standards or requirements unique to that specialty, as well as generic skills required for all counsellors. These bodies often create competitions for counsellors that training programmes may want to incorporate. (Aluede, McEachern \& Kenny 2005). This is similar to that of Hungary that has several emerging specialties like counselling for high ability children, counselling for secondary school and higher education levels, counselling for refugees, family and partner counselling, educational counselling, pastoral counselling, organizational counselling, inter-cultural counselling, etc. The situation is however different in Nigeria as guidance and counselling programmes in most Nigeria universities are rather broad, thus encompassing every aspect of counselling at the expense of each of the emerging specializations in guidance and counselling. 
We have noted earlier that guidance and counselling programmes in Nigeria universities are largely defective in relation to dealing with students of higher education. Students in higher education have numerous counselling needs that include time management, family, career health and so on (Aluede, Imhonde \& Eguavoen, 2006). No doubt, the life period between 18 years and 25 years (the period most students enter and graduate from our colleges) bears the possibility of a number of crises. Helping student solve these crises (i.e. time-management, peer pressure, family concerns, career, and health including drug concerns) might be one of the most important tasks of college counselling, which ought to be an important aspect of counselling practice in Nigeria, is being ignored.

Guidance and counselling profession is a very dynamic one with new information about counselling approaches and techniques emerging everyday the world over. Therefore, there is the need for CASSON to provide continuing education programmes for counsellors in Nigeria. By this provision, we can learn new and emerging counselling skills. As it is today, it is most likely to find counsellors not undergoing any training beyond their initial university degrees. Many of these degrees in counselling related fields may have even been acquired in the past two decades. And skills acquired under such situations, particularly for a dynamic specialty like counselling would have become obsolete. It is in this regard that CASSON is urged to make it mandatory for her members to undergo professional training programmes at least 3 months in every two years

The newly introduced health insurance scheme makes no provision for mental health as a component of the entire health scheme in Nigeria. CASSON is hereby urged to seek a responsibility in the Nigerian health system. This can be achieved by partnering with other mental health professionals such as social work and clinical psychology with a view to lobbying the National Assembly for a legislation that will include mental health as a component in the newly introduced Nigerian Health Insurance Scheme (NHIS). This 
will be one sure way of clearly defining the professional duties and qualifications of a counsellor-as to who should counsel. That is to say, recognizing counselling as a component of the entire health scheme will help to strengthen the capacity of counselling practice in Nigeria. Also, it will provide a basis for private practice in Nigeria, an aspect that is rarely talked about in counselling circle. This will further help to check the current practice that allows virtually anybody to counsel or claim to be a counsellor.

\section{Concluding Remarks}

Guidance and counselling profession will certainly be accorded an enviable status in Nigeria if the Counselling Association of Nigeria (CASSON) is able to make the Nigerian society recognize that it has a unique contribution to an individual's total well being. Through licensure, certification, continuing education and more importantly, pressuring for the inclusion of counselling as an aspect of the Nigerian health scheme, CASSON would have provided a professional identity for its members.

\section{References}

Aluede, O. O. (2000). The realities of Guidance and Counselling in Nigeria Secondary Schools: Issues and benefits. Guidance and Counselling 15 (2). $22-26$

Aluede, O., Afen-Akpaida, J. E. \& Adomeh, I.O.C. (2004). Some thought about the Future of Guidance and Counselling in Nigeria Schools. Education 125 (2), 296 - 305

Aluede, O. Mc Eachern, A. G. \& Kenny, M.C. (2005). Counselling in Nigeria and the United States. Contrasts and Similarities. International journal for the Advancement of Counselling 27, $371-383$

Aluede, O \& Imonikhe, J. S. (2006). Guidance and counselling in schools. In O. Aluede (Ed.). Guidance and counselling for 
Nigerian schools (pp1- 21). Agbor, Nigeria: Krisbec Publications

Aluede, O. (2006). Comprehensive guidance programme for Nigerian schools. Pakistan Journal of Education, XXIII (1), 75- 82.

Aluede, O. O. \& Maliki, A. E. (2000). Integrating Multiculturalism into Counselling education curriculum in Nigeria universities. African Journal of Education 5 (1),27-36

Aluede, O. O., Imhonde, H. O. \& Eguavoen, ANT (2006) Academic, career and personal needs of Nigerian universities students. Journal of Instructional Psychology, 33 (1), 50 - 62

Bojuwoye, O. (1992). The role of counselling in developing countries: A reply to Soliman International Journal for the Advancement of Counselling. 15, 2 - 16

Hui, E. K. P (2000) Guidance as a whole approach in Hong Kong: From remediation to students development International Journal for the Advancement of Counselling 22, 69-82

Federal Government of Nigeria (2004) . National Policy on Education (Revised Education). Abuja: NERDC. Press.

Gibson, R. L. \& Mitchell, M. H. (2003). Introduction to guidance and counselling ( $6^{\text {th }}$ edition). Upper Saddle River, N. J: Prentice Hill

Iwuuma, B. C. (1998). School Counselling in Nigeria Today and Tomorrow. Journal of Educational System, Research and Development 1 (2), 8 - 18.

Odebunmi, A. (1985). Psychological approach to guidance and counselling. Unpublished manuscript

Parrot, L. (1997). Counselling and Psychotherapy. New York: McGraw Hill.

Ritook, M. (1998) Counselling in Hungary: Past and future trends. International Journal for the Advancement of Counselling 20, $17-25$

Schmidt, J. J. (1993). Counselling in schools: Essential services and comprehensive programs. Boston, MA: Allyn and Bacon. 
A Roadmap to the Professionalization of

United Nations Educational, Scientific and Cultural Organization (UNESCO). (2002). Handbook on career counselling: $A$ practical manual for developing, implementing and assessing career counselling services in higher education setting. Paris: Author. 